\title{
Epidemiological Profile of Malignant Brain Neoplasms in the Northern Region of Brazil: data from the Cancer Hospital Registry of the Instituto Nacional de Câncer
}

\section{Perfil epidemiológico das neoplasias primárias malignas do encéfalo na região Norte do Brasil: dados dos Registros Hospitalares de Câncer do Instituto Nacional de Câncer}

\author{
Carlos Eduardo Adriano Filho ${ }^{1}$ Lenon Machado Pinto ${ }^{2}$ Joel Monteiro de Jesus ${ }^{2,3}$ \\ ${ }^{1}$ Center of Biological and Health Sciences, Universidade do Estado do \\ Pará, Belém, PA, Brazil \\ ${ }^{2}$ Course of Medicine, Universidade do Estado do Pará, Belém, PA, Brazil \\ Address for correspondence Carlos Eduardo Adriano Filho, Medical \\ Student, Universidade do Estado do Pará, Rua do Una, 156, Telégrafo,
}

${ }^{3}$ Neurosurgery Service, Hospital Ophir Loyola, Belém, PA, Brazil

Arq Bras Neurocir 2019;38:94-101.

\begin{abstract}
Objective Tumors of the central nervous system (CNS) are considered rare, with an incidence of 3.4 cases per 100,000 individuals worldwide. Although uncommon, CNS tumors have been gaining epidemiological importance due to their increased incidence and mortality. In Brazil, there is a lack of population research regarding CNS cancer, especially in the Northern region. Thus, the authors aim to trace an epidemiological profile of malignant brain neoplasms in the Northern region from 2001 to 2013.

Methods Data were collected from the Cancer Hospital Registry of the Instituto Nacional de Câncer (RHC-INCA, in the Portuguese acronym) and stratified according to origin, gender, age, detailed primary location, and histological type. A total of 742 cases were analyzed. Most of the cases came from inland areas, with a male predominance.

Results The most affected age groups were between 0 and 9 years old and between 30 and 49 years old, with an accentuated decrease in incidence starting at the age of 70 years old. The frontal lobe was the most affected area, followed by the temporal and parietal lobes. Astrocytic tumors accounted for $64.3 \%$ of cases, followed by embryonal tumors (18.2\%), and ependymal tumors (7.4\%). Among the astrocytic tumors, astrocytoma, not otherwise specified (NOS), and glioblastoma, NOS corresponded

Keywords

- brain neoplasms

- malignant neoplasm

- epidemiology to $82.2 \%$ of the cases. Among embryonal tumors, medulloblastoma accounted for $71.9 \%$ of the cases.

Conclusion More epidemiological studies in this area, especially in the Northern region, are required to identify risk factors and allow prevention and early diagnosis.
\end{abstract}

received

April 7, 2017

accepted

May 9, 2017
DOI https://doi.org/

$10.1055 / \mathrm{s}-0037-1603762$.

ISSN 0103-5355.
Copyright (e 2019 by Thieme Revinter

Publicações Ltda, Rio de Janeiro, Brazil
License terms

(c) $(1) \$$ 


\section{Resumo}
Palavras-chave
- neoplasias encefálicas
- neoplasia maligna
- epidemiologia

Objetivo Os tumores do sistema nervoso central (SNC) são considerados raros, com incidência de 3,4 casos a cada 100 mil indivíduos no mundo. Apesar de serem considerados raros, os tumores do SNC vêm ganhando importância epidemiológica devido ao aumento de sua incidência e mortalidade. No Brasil, há carência de pesquisas populacionais quando se trata de câncer no SNC, principalmente no Norte do país. Dessa forma, os autores objetivam traçar o perfil epidemiológico das neoplasias encefálicas malignas na região Norte de 2001 a 2013.

Métodos Os dados foram coletados dos Registros Hospitalares de Câncer do Instituto Nacional de Câncer (RHC-INCA) e estratificados em: procedência, gênero, faixa etária, localização primária detalhada e tipo histológico. Foram analisados 742 casos. A maioria dos pacientes teve procedência de cidades interioranas, e houve predominância do sexo masculino.

Resultados As faixas etárias mais acometidas foram de 0 a 9 anos e de 30 a 49 anos, com decréscimo acentuado a partir dos 70 anos. O lobo frontal foi o mais acometido, seguido pelos lobos temporal e parietal. Os tumores astrocíticos compuseram $64,3 \%$ do total, seguido pelos tumores embrionários (18,2\%) e ependimários (7,4\%). No grupo dos tumores astrocíticos, o astrocitoma, sem outra especificação (SOE), e o glioblastoma, SOE corresponderam a $82,2 \%$ dos casos. No grupo dos tumores embrionários, o meduloblastoma correspondeu a $71,9 \%$.

Conclusão Ressalta-se a necessidade de mais estudos epidemiológicos nessa área, especialmente na região Norte, com vistas à identificação de fatores de risco, prevenção e diagnóstico precoce na população.

\section{Introduction}

Primary tumors of the central nervous system (CNS) are considered rare, with an incidence of 3.4 cases per 100,000 individuals worldwide. ${ }^{1}$ However, knowledge about these tumors is still restricted in the medical literature.

Statistics from the United States indicate an incidence of 117,023 malignant cases between 2008 and 2012, with the most frequent brain location at the frontal, temporal, and parietal lobes. $^{2}$

In Brazil, it is estimated that 10,270 new cases of primary CNS neoplasms occurred in 2016, more than a half of these in men. The most affected region is the Southeast, with 4,210 cases. In the Northern region, 420 cases were estimated, mostly in men (54.7\%). This type of cancer is the tenth most frequent in the region. It is estimated that the rate of these tumors per 100,000 individuals is of 2.62 cases for men and of 2.21 cases for women. ${ }^{3}$ Although rare, CNS neoplasms are among the deadliest, and only half of the diagnosed individuals survive for 1 year after the diagnosis. ${ }^{4}$

In Brazil, there is a lack of populational research regarding CNS cancer, especially in the Northern region. The need for further epidemiological studies on these neoplasms has already been evidenced in systematic reviews and meta-analyses. ${ }^{5}$

Although this is a constantly evolving area in the medical literature, developing countries, such as Brazil, suffer from deficiencies in the screening of suspected cancer cases. With 7 states and a total estimated population of 17,707,783 inhabitants, ${ }^{6}$ the Northern region has one of the lowest Human Development Indexes of Brazil, and it is still plagued by infrastructure shortages, such as lack of hospitals and difficult access to reference hospitals; these factors contribute to deficient records, implying the need for research and studies on the regional epidemiological profile of brain tumors. As such, the authors aim to trace an epidemiological profile of primary brain malignant neoplasms in the Northern region from 2001 to 2013.

\section{Materials and Methods}

This is a descriptive, longitudinal, retrospective study. The present research complied with the ethical precepts established by CNS $466 / 12$, and its preliminary project was approved by the Nucleus of Research and Extension in Medicine and Research Ethics Committee under the protocol number 07/15. Data collection was performed at the José de Alencar Gomes da Silva database of the Cancer Hospital Registry of the Instituto Nacional de Câncer (RHC-INCA, in the Portuguese acronym)).

State health departments submit RHC information to the INCA, who builds a consolidated national base after the elimination of multiplicities. Nine hospitals from the Northern region sent primary CNS neoplasms data to the INCA system during the period analyzed; two hospitals from Pará and Tocantins, and one hospital from each of the remaining states (Acre, Amazonas, Amapá, Roraima, and Rondônia).

Data from patients enrolled in the RHC-INCA database who were diagnosed with primary malignant brain neoplasms in the Northern region between January 2001 and December 2013 were included. Data were stratified for further analysis 


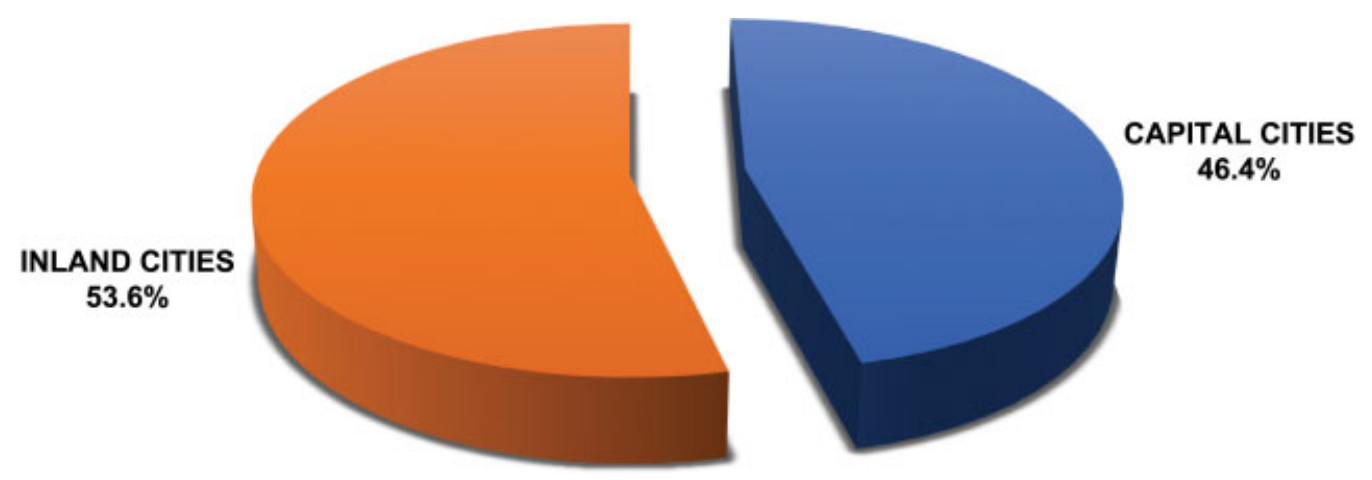

Fig. 1 Distribution by origin of central nervous system primary malignant neoplasm cases at the Northern region reported at RHC/INCA from 2001 to 2013. Source: Cancer Hospital Registry (Registro Hospitalar de Câncer, RHC) - Brazilian National Cancer Institute (Instituto Nacional de Câncer, INCA).

according to origin, gender, age group, detailed primary location, and histological type. To assure data reliability, the authors analyzed the records included in the RHC-INCA database, excluding those from patients who were not diagnosed with primary brain malignancies, not originating from the Northern region, not pertaining to the investigated period, and who were deemed insufficient for the assessment required in the present study, such as incompletely filled or blank forms.

The information obtained was organized in a database and submitted to statistical analysis using Microsoft Office Excel 2016 (Microsoft Corporation, Redmond, WA, USA) and TabWin version 3.6 for Windows (DATASUS, Rio de Janeiro, RJ, Brazil). The chi-squared test was performed to investigate the association between gender or age and histological type. The null hypothesis rejection index was set at 0.05 , or $5 \%$.

Microsoft Office Excel 2016 software (Microsoft Corporation) was used to prepare the graphs and tables. Maps were prepared with TabWin software version 3.6 for Windows. This text was written using Microsoft Office Word 2016 (Microsoft Corporation, Redmond, WA, USA).

\section{Results}

There were 933 cases in the period studied, of which 191 met the exclusion criteria because their information was insufficient for an adequate analysis. Thus, a total of 742 cases were assessed, of which 344 originated in capital cities (46.4\%) and 398 in inland areas (53.6\%) (-Fig. 1). There were 428 male cases (57.7\%) and 314 female cases ( $42.3 \%$ ), with a statistically significant difference ( $p=0.0007)$ ( $\boldsymbol{- F i g . 2}$ ). The most affected age groups were between 0 and 9 years old (128 patients), and between 30 and 49 years old (115 patients), followed by between 40 and 49 years old (113 patients), with a marked decrease in incidence starting at the $7^{\text {th }}$ decade of life ( - Fig. 3 ). The primary detailed location could not be determined in $55.5 \%$ of the cases, being referred only as encephalon, not otherwise specified (NOS), or brain, NOS. However, in these patients, the frontal lobe was the most affected area (8.4\%), followed by the temporal lobes (6.1\%), and the parietal lobes (5.4\%). Neoplasms located in the cerebellum accounted for $17.9 \%$ of the cases (-Fig. 4). Astrocytic tumors corresponded to $64.3 \%$ of the cases, followed by embryonal tumors (18.2\%) and ependymal tumors (7.4\%) (-Fig. 5). Among the astrocytic tumors, astrocytoma, NOS (29.8\%), and glioblastoma, NOS (52.4\%) were the most frequent (-Fig. 6). In this group, the prevalence was higher in males ( $57.4 \%$ compared with $42.6 \%$ in females), with a statistically significant difference $(p=0.02)(-$ Fig. 7$)$. The number of affected patients increases with age, especially in those $>30$ years old, and it decreases in people $>70$ years old (-Fig. 8). Among the embryonal tumors, medulloblastoma, NOS, accounted for $71.9 \%$ of the cases, followed by neuroblastoma, NOS (8.9\%), and by primitive neuroectodermal tumor, NOS (8.9\%) (- Fig. 9). No statistically significant difference between genders was found in this group ( - Fig. 7). Approximately $45 \%$ of the patients were aged between 0 and 9 years old. The embryonal tumors was the most frequent histological type, among all of the analyzed ones, in this age group. About $70 \%$ of

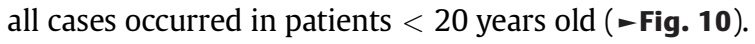

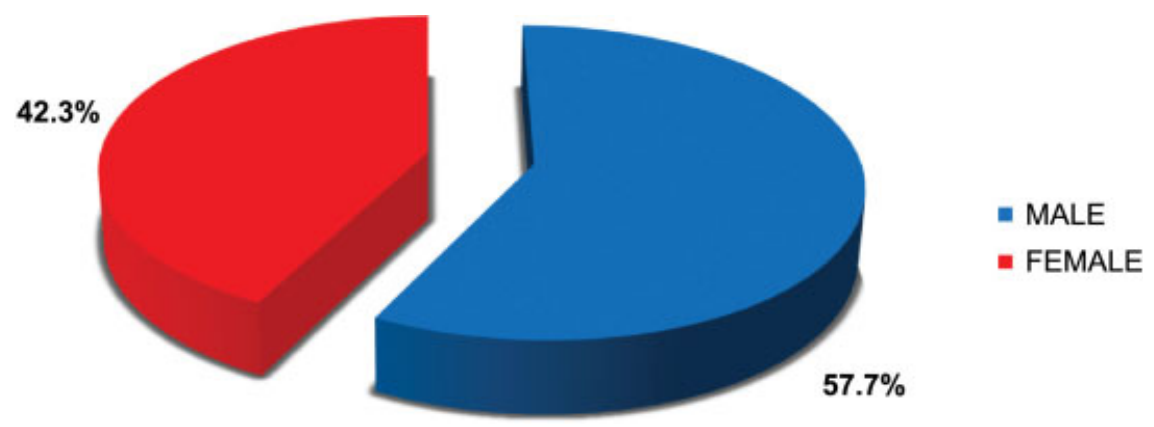

Fig. 2 Distribution by gender of central nervous system primary malignant neoplasm cases at the Northern region reported at RHC/INCA from 2001 to 2013. Source: Cancer Hospital Registry (Registro Hospitalar de Câncer, RHC) - Brazilian National Cancer Institute (Instituto Nacional de Câncer, INCA). $p<0.05$. 


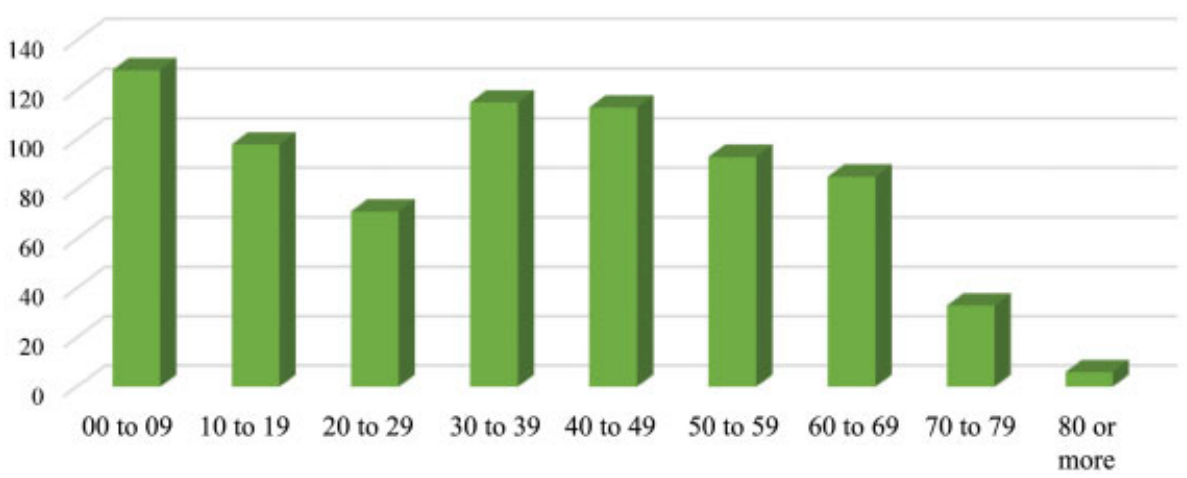

Fig. 3 Distribution by age group 'of central nervous system primary malignant neoplasm cases at the Northern region reported at RHC/INCA from 2001 to 2013. Source: Cancer Hospital Registry (Registro Hospitalar de Câncer, RHC) - Brazilian National Cancer Institute (Instituto Nacional de Câncer, INCA).

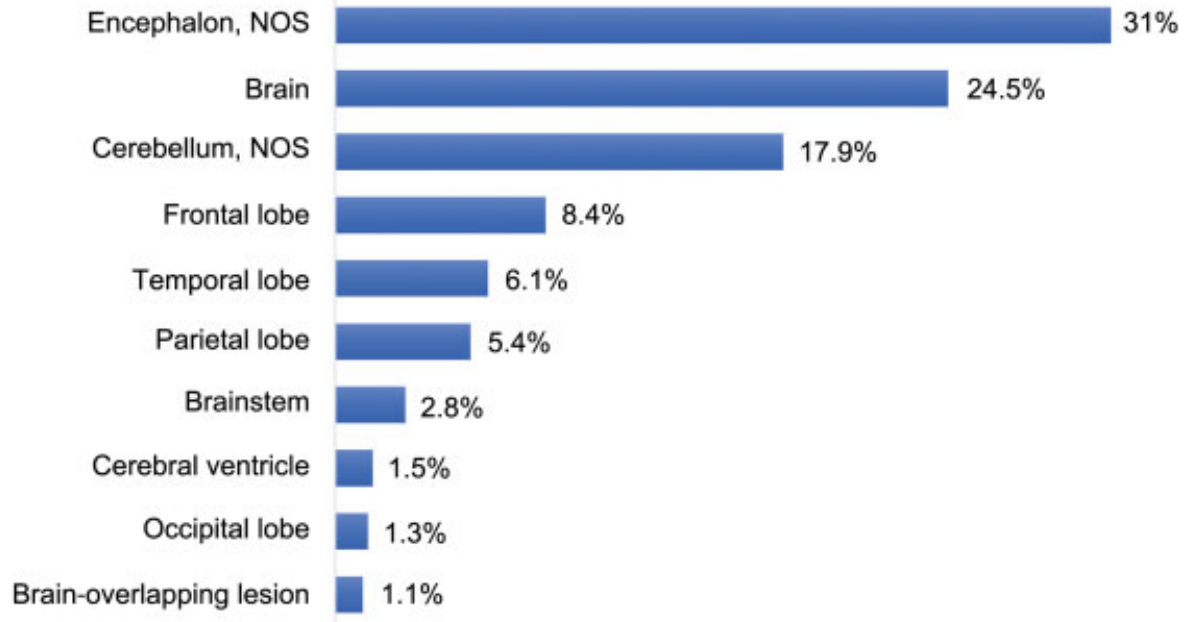

Fig. 4 Distribution by detailed primary location of central nervous system primary malignant neoplasm cases at the Northern region reported at RHC/INCA from 2001 to 2013. Abbreviations: NOS, not otherwise specified. Source: Cancer Hospital Registry (Registro Hospitalar de Câncer, RHC) - Brazilian National Cancer Institute (Instituto Nacional de Câncer, INCA).

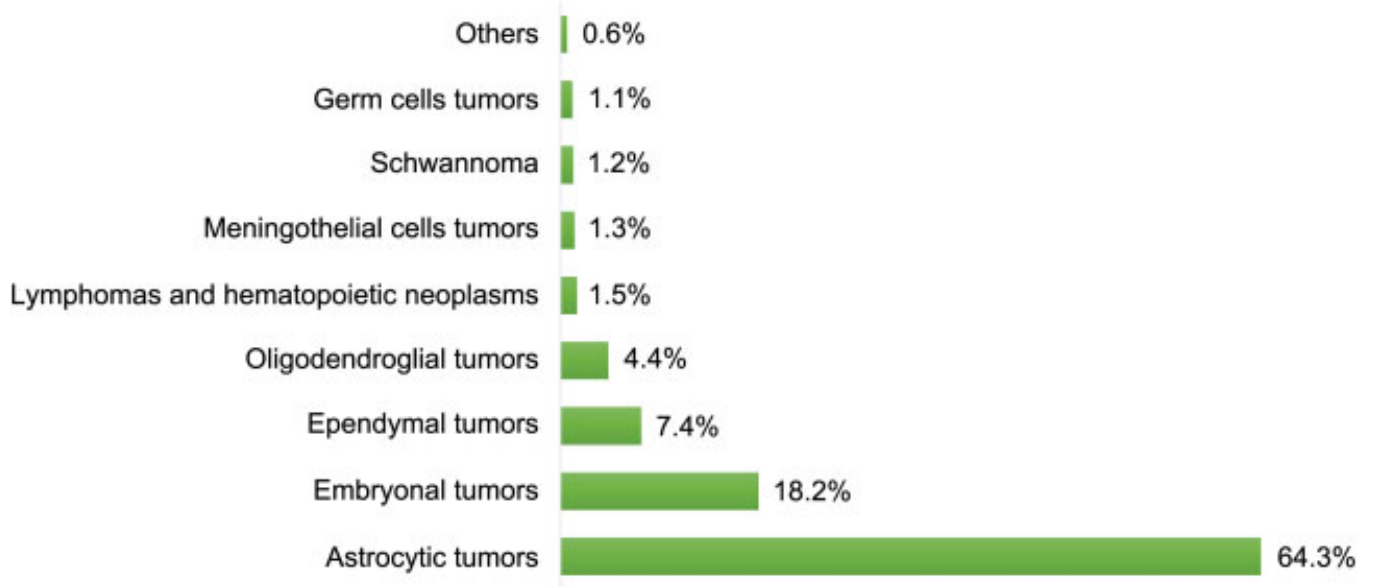

Fig. 5 Distribution by group or World Health Organization (WHO) histological type of central nervous system primary malignant neoplasm cases at the Northern region reported at RHC/INCA from 2001 to 2013. Source: Cancer Hospital Registry (Registro Hospitalar de Câncer, RHC) Brazilian National Cancer Institute (Instituto Nacional de Câncer, INCA).

\section{Discussion}

The establishment of effective cancer control measures requires quality information about the prevalence, the char- acterization, and the mortality distribution, allowing a better understanding of the disease and its determinant factors, the formulation of causal hypotheses, the assessment of technological advances applied to prevention and treatment, as well 
98 Epidemiological Profile of Malignant Brain Neoplasms in the Northern Region Adriano et al.

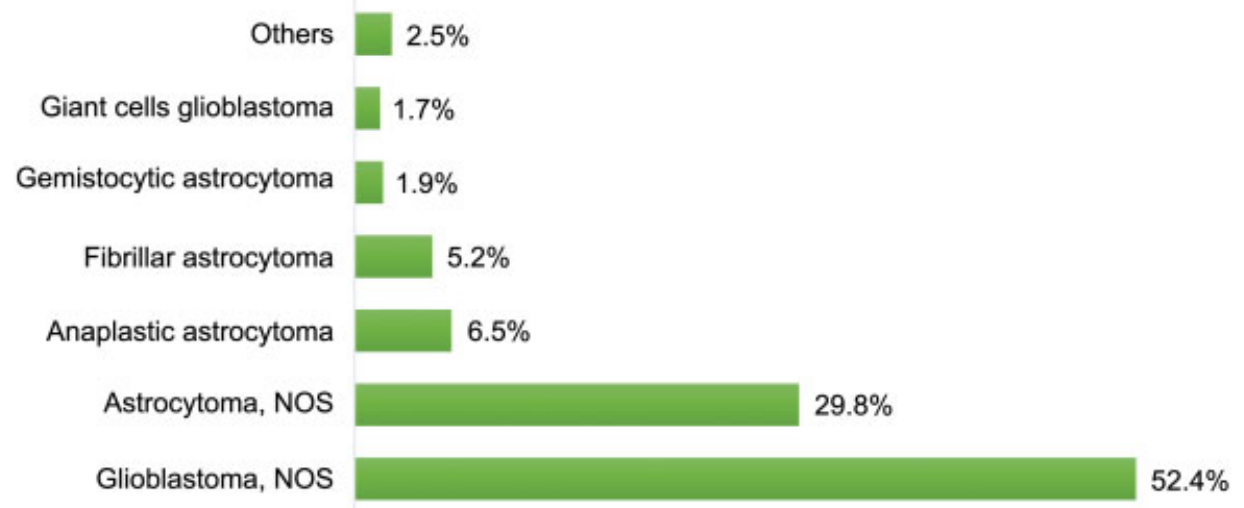

Fig. 6 Distribution after astrocytic tumors stratification of central nervous system primary malignant neoplasm cases at the Northern region reported at RHC/INCA from 2001 to 2013. Abbreviations: NOS, not otherwise specified. Source: Cancer Hospital Registry (Registro Hospitalar de Câncer, RHC) - Brazilian National Cancer Institute (Instituto Nacional de Câncer, INCA).

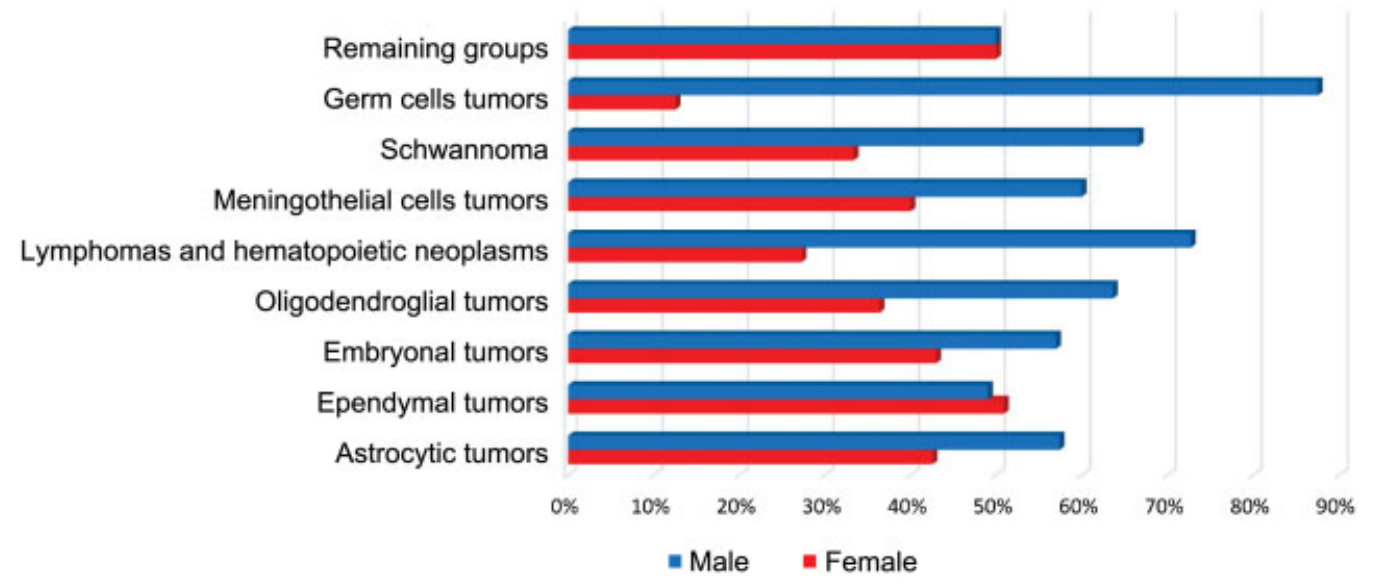

Fig. 7 Distribution by World Health Organization (WHO) histological type and gender of central nervous system primary malignant neoplasm cases at the Northern region reported at RHC/INCA from 2001 to 2013. Source: Cancer Hospital Registry (Registro Hospitalar de Câncer, RHC) Brazilian National Cancer Institute (Instituto Nacional de Câncer, INCA). In astrocytic and germ cells tumors: $p<0.05$.

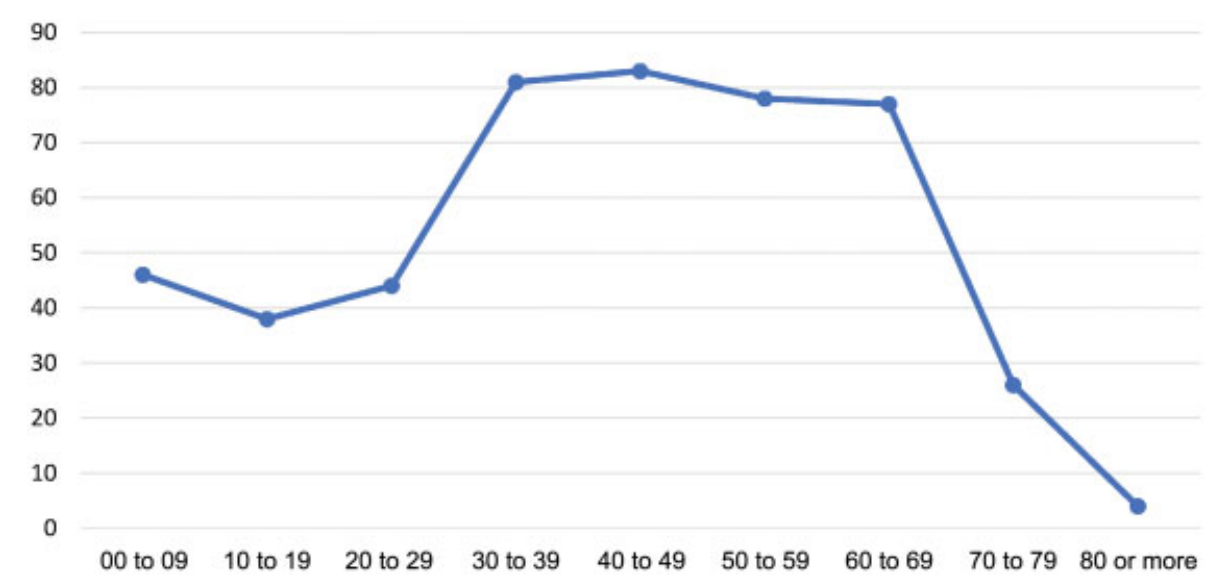

Fig. 8 Distribution after age group stratification in the group of astrocytic tumors of central nervous system primary malignant neoplasm cases at the Northern region reported at RHC/INCA from 2001 to 2013. Source: Cancer Hospital Registry (Registro Hospitalar de Câncer, RHC) Brazilian National Cancer Institute (Instituto Nacional de Câncer, INCA).

as an improved effectiveness in health care. ${ }^{7}$ This context calls for cancer registries, which consolidate themselves as fundamental pillars of epidemiological cancer surveillance. These registries are essential sources for epidemiological and clinical research and for the planning and evaluation of cancer control actions. ${ }^{8}$ In Brazil, cancer registries are now legally protected, especially since the publication of the ordinance GM/MS No. 3,535/98, establishing mandatory RHC functioning. ${ }^{9}$ 


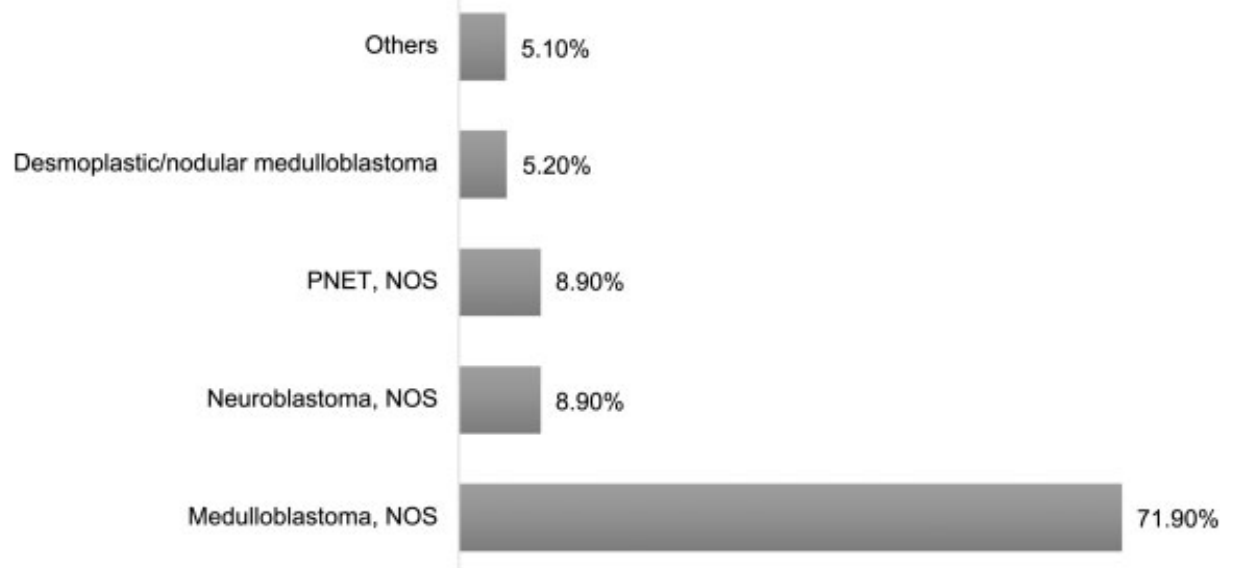

Fig. 9 Distribution after embryonal tumors type stratification of central nervous system primary malignant neoplasm cases at the Northern region reported at RHC/INCA from 2001 to 2013. Abbreviations: NOS, not otherwise specified; PNET, Primitive neuroectodermal tumor. Source: Cancer Hospital Registry (Registro Hospitalar de Câncer, RHC) - Brazilian National Cancer Institute (Instituto Nacional de Câncer, INCA).

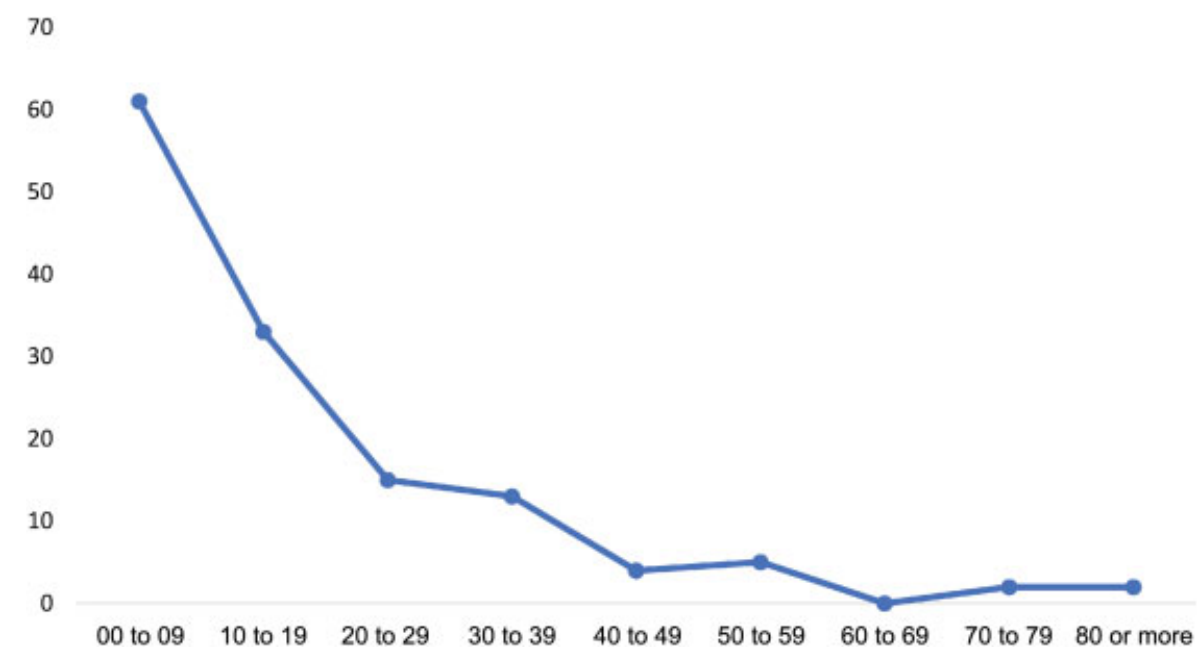

Fig. 10 Distribution after age group stratification in the group of embryonal tumors of central nervous system primary malignant neoplasm cases at the Northern region reported at RHC/INCA after from 2001 to 2013. Source: Cancer Hospital Registry (Registro Hospitalar de Câncer, RHC) - Brazilian National Cancer Institute (Instituto Nacional de Câncer, INCA).

The present study found that $53.6 \%$ of the patients came from inland areas. This can be explained by the structure of the Brazilian Unified Health System (SUS, in the Portuguese acronym), based on health care networks subdivided into three levels: primary, secondary, and tertiary; tertiary care, however, concentrates in large cities. Since cancer is a complex disease, requiring the incorporation of specialized teams with higher technological density, services that treat brain tumors patients belong to the tertiary level. As a result, inland patients seek out reference hospitals in capital cities. This is more evident in poorer areas and in places with restricted access to health care services, such as the Northern region. ${ }^{10}$

The present study showed a male predominance in seven of the nine histological groups, with statistically significant differences for astrocytic and germ cells tumors. In the United States, the incidence of primary CNS tumors was higher in women (57.9\%) than in men (42.1\%). However, male patients are the most affected by malignant neoplasms. In addition, the incidence of tumors located in the brain, in the ventricles, and in the cerebellum was also higher in men. ${ }^{2}$
Other studies have also shown that more male patients were affected. ${ }^{11-13} \mathrm{~A}$ meta-analysis revealed an incidence of 15.8 cases per 100,000 inhabitants in women and of 14.33 in 100,000 inhabitants in men; however, this difference was not statistically significant. ${ }^{5}$ Our data, however, disagree with the incidence rates reported by other authors. ${ }^{14,15}$ This discrepancy may be explained by the higher number of meningiomas found in these studies, since these tumors (mostly primary and benign) are more frequent in women, and the presence of female hormone receptors in this neoplasm has been demonstrated. ${ }^{16}$

The reason for the higher incidence in men compared with women has yet to be determined; however, genetic, regional, and population differences may play a role. The effects of gender in cancer occur at several levels, that is, cell transformation, tumoral tissue organization, and in the body as a whole, resulting from the influence of immunity and of sex hormones. Some genetic alterations found in glioblastomas, such as neurofibromin loss, PTEN and p53 gene mutations, and plateletderived growth factor receptor, are more frequent in men. ${ }^{17}$ 
Tumor location is an important factor for the evaluation and staging of neoplasms, serving as a parameter for the prognosis. The present study found the highest number of cases in the frontal, temporal and parietal lobes. At a North American study, the most frequent location was the frontal lobe, followed by the temporal lobe, overlapping brain lesion, and the parietal lobe. ${ }^{18}$

Another author showed that brain parenchyma tumors were more frequently located in the frontal lobe, followed by the cerebellum, the temporal lobe, and the parietal lobe. ${ }^{19}$ Tumoral regional and behavioral differences in each population may explain data disagreements; however, more studies are required. The large number of cerebellar cases can be explained by the frequent presence of medulloblastomas, which have a unique cerebellar location.

In the present study, astrocytomas and glioblastomas were the most frequent histological types. This finding is observed in other literary studies regarding malignant primary CNS neoplasms. ${ }^{2,20-22}$

Europe had a substantial increase in the incidence of astrocytomas and of glioblastomas in patients $>40$ years old, with a peak at the $6^{\text {th }}$ decade of life. ${ }^{23}$ Similar results were also reported elsewhere. ${ }^{24-26}$ These studies, however, suggest that the decrease in the incidence starts at 80 years old. In the present study, we have verified that this phenomenon starts in the $7^{\text {th }}$ decade of life.

The medical literature still debates why recent epidemiological studies show an increase in primary brain neoplasms, especially malignant ones, in the elderly. The debate is whether there is a real incidence increase, caused by risk factors not yet known, or if the phenomenon reflects the improved diagnostic techniques. The literature agrees on the need for further research. In our study, medulloblastoma, NOS, corresponded for $70 \%$ of embryonal tumor cases. This histological group accounts for most primary, high-grade tumors in children and adolescents, with medulloblastoma as the main histological type. The male gender seems to be the most affected. ${ }^{27,28}$ Boys are $46 \%$ more likely to have a medulloblastoma than girls. ${ }^{29}$

Pilocytic astrocytoma remains the main primary CNS tumor in childhood and adolescence; however, it is mostly benign. ${ }^{30-32}$ Thus, although it is not the most frequent tumor in children and adolescents, medulloblastoma remains one of the main brain neoplasms in this age group.

Recent years witnessed an increase in the number of primitive neuroectodermal tumor (PNET) cases. In the present study, this tumor accounted for $8.9 \%$ of the embryonal tumors. The increased incidence may be explained by changes in the classification of brain tumors in the 1980 s. $^{33}$ Until then, medulloblastomas and PNETs were not considered distinct tumors. However, later studies showed that PNETs can reach the suprasellar region and the cerebellum; moreover, they present different molecular characteristics. Children are 4.6 times more likely to present PNETs than adults. ${ }^{34}$

It should be noted that the present study has limitations; Brazilian epidemiological information still needs to be improved. The present study was performed in this context.
Because of the wide geographic coverage, poor health care services, and poor access to hospitals in many places, the presented data may underestimate the actual situation of the Northern region.

Even though cancer treatment institutions are legally required to have RHC systems and to report their data to health departments, deficiencies are likely to occur. In the period analyzed, there were 933 cases registered in RHC-INCA. However, the INCA estimated that, in 2016 alone, there would be 420 cases in the Northern region. As such, the national database seems to be far from the reality. During the data survey for the present study, we found inconsistencies in the data of some patients, such as blank or incorrectly filled forms. Basic information, such as the detailed tumor location, was not reported in $55 \%$ of the cases from the present study. Since the $\mathrm{RHC}$ is a computerized system, it is possible that data from paper medical records are lost when entered in the RHC database, especially in hospitals with no electronic medical record system. Likewise, it is critical that state health departments submit collected data to the INCA. Difficulties faced by Brazilian researchers conducting an epidemiology study require special attention from health teams and managers, since these data will base the planning of health care actions.

We highlight the need to properly train health care teams in RHC in each hospital to improve its use. Coordination between federal, state, and municipal governments is required to adequately equip cancer-treating hospitals, especially those that treat CNS tumors in the Northern region.

In addition, we suggest further specific epidemiological studies, especially in Brazil, since we lack data to better understand the genesis, the diagnosis, and the prognosis of primary CNS tumors in the country.

\section{Conclusion}

Analyzing the 742 cases, it is possible to conclude that most of the patients came from inland areas and were male. The most affected age groups were between 0 and 9 years old and between 30 and 49 years old, with a marked decrease starting at 70 years old. The frontal lobe was the most affected region, followed by the temporal and parietal lobes. Astrocytic tumors accounted for $64.3 \%$ cases, followed by embryonal tumors (18.2\%), and ependymal tumors (7.4\%). Among the astrocytic tumors, astrocytoma, NOS, and glioblastoma, NOS, corresponded to $82.2 \%$ of the cases. Among embryonal tumors, medulloblastoma accounted for $71.9 \%$ of the cases.

Conflicts of Interest

The authors have no conflicts of interest to declare.

\section{References}

1 Ferlay J, Soerjomataram I, Dikshit R, et al. Cancer incidence and mortality worldwide: sources, methods and major patterns in GLOBOCAN 2012. Int J Cancer 2015;136(05):E359-E386

2 Ostrom QT, Gittleman H, Fulop J, et al. CBTRUS Statistical Report: Primary Brain and Central Nervous System Tumors Diagnosed in the United States in 2008-2012. Neuro-oncol 2015;17(Suppl 4):iv1-iv62 
3 Instituto Nacional de Câncer. Coordenação de prevenção e vigilância. Estimativa 2016: Incidência de câncer no Brasil. Rio de Janeiro, RJ: Instituto Nacional de Câncer; 2015

4 Gasparini B. Mortalidade por tumores do sistema nervoso central no Município do Rio de Janeiro, 1980-2007 [thesis]. Rio de Janeiro: Escola Nacional de Saúde Pública; 2010

5 de Robles P, Fiest KM, Frolkis AD, et al. The worldwide incidence and prevalence of primary brain tumors: a systematic review and meta-analysis. Neuro-oncol 2015;17(06):776-783

6 Instituto Brasileiro de Geografia e Estatística. Estimativas da população residente no Brasil e unidades da federação com data de referência em $1^{\circ}$ de julho de 2016. Available at: ftp:// ftp.ibge.gov.br/Estimativas_de_Populacao/Estimativas_2016/estimativa_TCU_2016_20170614.pdf; 2016

7 Ferla AA, Ceccim RB, Dall'alba R. Informação, educação e trabalho em saúde: para além de evidências, inteligência coletiva. R Eletr de Com Inf Inov Saúde 2012;6:2

8 Brasil. Ministério da Saúde. Departamento de Ciência e Tecnologia. Secretaria de Ciência e Tecnologia e Insumos Estratégicos. Integração de informações dos registros de câncer brasileiros. Rev Saude Publica 2007;41(05):865-868

9 Ministério da Saúde (Brasil). Portaria 3.535, de 2 de setembro de 1998. Estabelece critérios para cadastramento de centros de atendimento em oncologia

10 Mendes EV. As redes de atenção à saúde. $2^{\mathrm{a}}$ ed. Brasília: Organização Pan-Americana de Saúde; 2011

11 López-Abente G, Pollán M, Ardanaz E, Errezola M. Geographical pattern of brain cancer incidence in the Navarre and Basque Country regions of Spain. Occup Environ Med 2003;60(07): 504-508

12 Pirouzmand F, Sadanand V. The incidence trends of primary brain tumors in Saskatchewan from 1970 to 2001. Can J Neurol Sci 2007;34(02):181-186

13 Wöhrer A, Waldhör T, Heinzl H, et al. The Austrian Brain Tumour Registry: a cooperative way to establish a population-based brain tumour registry. J Neurooncol 2009;95(03):401-411

14 Jiang T, Tang GF, Lin Y, et al. Prevalence estimates for primary brain tumors in China: a multi-center cross-sectional study. Chin Med J (Engl) 2011;124(17):2578-2583

15 Rodrigues DB, Lima LO, Pereira ELR, et al. Epidemiologia das neoplasias intracranianas no Hospital do Servidor Público Estadual de São Paulo: 2010-2012. Arq Bras Neurocir 2014;33(01): 6-12

16 Wigertz A, Lönn S, Mathiesen T, Ahlbom A, Hall P, Feychting M; Swedish Interphone Study Group. Risk of brain tumors associated with exposure to exogenous female sex hormones. Am J Epidemiol 2006;164(07):629-636

17 Sun T, Plutynski A, Ward S, Rubin JB. An integrative view on sex differences in brain tumors. Cell Mol Life Sci 2015;72(17): 3323-3342

18 Zada G, Bond AE, Wang YP, Giannotta SL, Deapen D. Incidence trends in the anatomic location of primary malignant brain tumors in the United States: 1992-2006. World Neurosurg 2012;77(3-4):518-524

19 Lee CH, Jung KW, Yoo H, Park S, Lee SH. Epidemiology of primary brain and central nervous system tumors in Korea. J Korean Neurosurg Soc 2010;48(02):145-152

20 Jazayeri SB, Rahimi-Movaghar V, Shokraneh F, Saadat S, Ramezani R. Epidemiology of primary CNS tumors in Iran: a systematic review. Asian Pac J Cancer Prev 2013;14(06):3979-3985

21 Mendes GA, Ongaratti BR, Lima JFSP. Epidemiologia de uma série de tumores primários do sistema nervoso central. Arq Bras Neurocir 2014;33(04):279-283

22 Gigineishvili D, Gigineishvili T, Tsiskaridze A, Shakarishvili R. Incidence rates of the primary brain tumours in Georgia-a population-based study. BMC Neurol 2014;14(01):29

23 Crocetti E, Trama A, Stiller C, et al; RARECARE working group. Epidemiology of glial and non-glial brain tumours in Europe. Eur J Cancer 2012;48(10):1532-1542

24 Manoharan N, Julka PK, Rath GK. Descriptive epidemiology of primary brain and CNS tumors in Delhi, 2003-2007. Asian Pac J Cancer Prev 2012;13(02):637-640

25 Dobes M, Shadbolt B, Khurana VG, et al. A multicenter study of primary brain tumor incidence in Australia (2000-2008). Neurooncol 2011;13(07):783-790

26 Caldarella A, Crocetti E, Paci E. Is the incidence of brain tumors really increasing? A population-based analysis from a cancer registry. J Neurooncol 2011;104(02):589-594

27 Katchy KC, Alexander S, Al-Nashmi NM, Al-Ramadan A. Epidemiology of primary brain tumors in childhood and adolescence in Kuwait. Springerplus 2013;2(01):58

28 Negreiros AALV, Monteiro LLD, Arruda RF, Ferreira CD. Aspectos Epidemiológicos dos Tumores do Sistema Nervoso Central Pediátricos em um Hospital de Referência de João Pessoa (PB) entre 2009 e 2011. Med Pesquisa 2015;1:1

29 McKean-Cowdin R, Razavi P, Barrington-Trimis J, et al. Trends in childhood brain tumor incidence, 1973-2009. J Neurooncol 2013; 115(02):153-160

30 Alexiou GA, Moschovi M, Stefanaki K, Sfakianos G, Prodromou N; Experience from the Agia Sofia Children's HospitalEpidemiology of pediatric brain tumors in Greece (1991-2008). Cent Eur Neurosurg 2011;72(01):1-4

31 El-Gaidi MA. Descriptive epidemiology of pediatric intracranial neoplasms in Egypt. Pediatr Neurosurg 2011;47(06):385-395

32 Harmouch A, Taleb M, Lasseini A, Maher M, Sefiani S. Epidemiology of pediatric primary tumors of the nervous system: a retrospective study of 633 cases from a single Moroccan institution. Neurochirurgie 2012;58(01):14-18

33 Pollack IF, Jakacki RI. Childhood brain tumors: epidemiology, current management and future directions. Nat Rev Neurol 2011;7(09):495-506

34 Smoll NR, Drummond KJ. The incidence of medulloblastomas and primitive neurectodermal tumours in adults and children. J Clin Neurosci 2012;19(11):1541-1544 